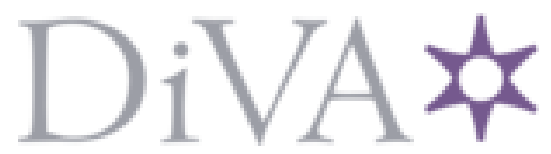

http://www.diva-portal.org

This is [Version unknown!] version of a paper published in International Journal of Educational Development.

Citation for the original published paper (version of record):

Wedin, Å. (2010)

Classroom interaction: Potential or problem?: The Case of Karagwe.

International Journal of Educational Development, 30(2): 145-150

https://doi.org/10.1016/j.ijedudev.2009.03.007

Access to the published version may require subscription.

N.B. When citing this work, cite the original published paper.

Permanent link to this version:

http://urn.kb.se/resolve?urn=urn:nbn:se:oru:diva-6261 
Provided for non-commercial research and education use. Not for reproduction, distribution or commercial use.

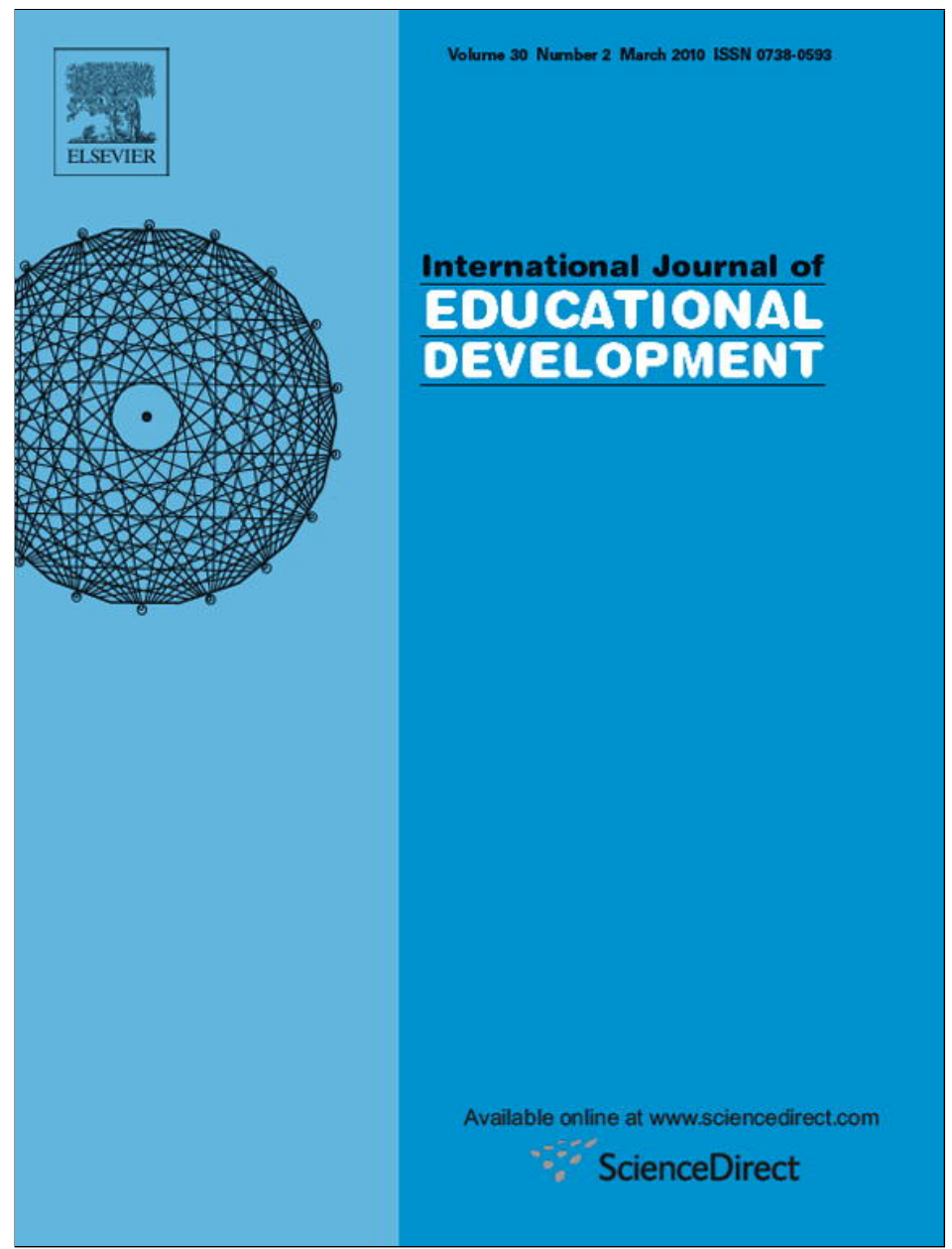

This article appeared in a journal published by Elsevier. The attached copy is furnished to the author for internal non-commercial research and education use, including for instruction at the authors institution and sharing with colleagues.

Other uses, including reproduction and distribution, or selling or licensing copies, or posting to personal, institutional or third party websites are prohibited.

In most cases authors are permitted to post their version of the article (e.g. in Word or Tex form) to their personal website or institutional repository. Authors requiring further information regarding Elsevier's archiving and manuscript policies are encouraged to visit:

http://www.elsevier.com/copyright 


\title{
Classroom interaction: Potential or problem? The case of Karagwe
}

\author{
Åsa Wedin * \\ HumES, University of Örebro, Örebro, Sweden
}

\section{A R T I C L E I N F O}

Keywords:

Educational policy

Development

Classroom interaction

Primary school

Call response

\begin{abstract}
A B S T R A C T
This paper discusses interactional patterns in classrooms in primary school in rural Tanzania, based on an ethnographic study on literacy practices. The paper argues that the official policy of Swahili-only in primary school, together with the huge gap between high expectations on educational outcome and lack of resources, have resulted in the creation of safety strategies among pupils and teachers. These safety strategies include interactional patterns that also constitute a hindrance for students' learning. However, I claim that these interactional patterns could constitute a potential for educational development, if research findings from bilingual education were taken into account.
\end{abstract}

(๖ 2009 Elsevier Ltd. All rights reserved.

\section{Introduction}

It is important that resources devoted to education are used effectively and that the education is relevant for students. This is particularly important in poor countries, such as Tanzania, as lack of resources is a big problem. In Karagwe district in Tanzania, educational outcome is low, as in many parts of Africa. This is wellknown and there are many factors behind that, such as lack of teaching materials, well-trained teachers, and relevant school buildings (Brock-Utne, 2000; Buchert, 1994; Wedin, 2004). The role of language as a medium of instruction in education in Africa is discussed in many contexts. Many researchers have discussed the fact that the use of English for instruction in secondary school in Tanzania causes great problems for educational outcome in secondary school, as neither teachers nor students master English at a sufficient level (see for example Trappes-Lomax, 1990; Lwaitama and Rugemalira, 1990; Rubagumya, 1994). However, the role of language as a medium of instruction in primary schools in Tanzania is seldom discussed.

Researchers have shown that there are two common assumptions that seem to be held by educational policy makers in Tanzania (Brock-Utne, 2000; Rubagumya, 1990, 1994; Blommaert, 1996). The first one is that all children in Tanzania master Swahili when they begin school and the second is that using a foreign language such as English as medium of instruction in school is a good way of teaching students that language. Thus, primary school education is carried out in Swahili and teachers are

\footnotetext{
* Correspondence address: Department of Education, Örebro University, Fakultetsgatan 1, SE-701 82 Örebro, Sweden. Tel.: +46 19301281.

E-mail address: asa.wedin@oru.se.
}

not advised, through curricula, schoolbooks and manuals, how to handle the fact that Swahili is a second language for the majority of the children. English is used as the medium of instruction from secondary school level and the status of English in Tanzania is increasing. That, in combination with the later assumption, that an effective way of teaching children English is to make it the medium of instruction also of primary school, has resulted in a mushrooming of English medium primary schools in Tanzania around the turn of the millennium. In this paper, I will challenge the first one of these assumptions, that children in Tanzania master Swahili when they begin school. I also aim at showing that existing policies have resulted in interactional patterns in school that constitute a hindrance for students' learning. I also aim at showing that if these interactional patterns were developed, based on relevant research on bilingual education and in accordance with the ways similar patterns are used in society, they could be turned into an asset for educational development in Tanzania.

\section{Methods and approaches}

This paper is based on a study I carried out during the period of 1999-2003 on literacy practices in Karagwe. I studied people's use of and attitudes to written language and tried to find ways to make literacy education in school more relevant to the students' future lives, by linking what happens in school with what happens in society. I spent 10 months in the area, divided into five field studies during 2000-2003, observing literacy practices in different settings, such as in schools, offices, homes, churches, market places and in other domains where people spent their days. One important obstacle for effective and relevant literacy education I identified, and that is the topic of this paper, was interactional 
patterns in classrooms that I claim are a result of language patterns and language choice in primary school (see Wedin, 2004, 2005).

The study was carried out using an ethnographic perspective. This means that it was concerned with the study and cultural interpretation of behaviour in naturally ongoing settings. Ethnographic methods, which strive to give a holistic/contextual, comparative and cross-cultural picture on the phenomenon in focus, are particularly appropriate where deeper understandings are searched for. Ethnography concerns issues of human choice and meaning, and in that sense it concerns issues of improvement in educational practices and is thus highly relevant for educational research (Ericksson, 1986). The interpretative approach enables the creation of information that is valuable in educational planning.

Interviews were carried out with children, teachers and parents both formally and informally in different settings in the society. I carried out formal interviews with children from different classes, apart from all informal contacts I had with numerous children. By interacting with children inside and outside schools I tried to get an understanding of their views. As the society is strictly hierarchical, formal interviews with children particularly in school settings are problematic. Observations in different areas where people spend their time, was also an important part of the study. In order to understand how students' learned, including their level of understanding of what was taught at school, I observed classes, studied the pupils' exercise books and carried out follow-up interviews a few days after observed lessons. I also studied teachers planning books and interviewed teachers before and after lectures.

\subsection{The setting}

Karagwe district is located in Kagera in the north-west of Tanzania, bordering to Uganda and Rwanda. The Banyambo, who inhabit Karagwe, number about 500,000. This was traditionally a hierarchical society, with ruling pastoralist clans and a number of agriculturalist clans. The language of the Banyambo, Runyambo, is one of the Western-Lacustrine Bantu-languages together with neighbouring languages such as Ruhaya, Kinyankole and Kinyarwanda. The Arab traders introduced Swahili and as the area was later colonized, first by the Germans and then by the British, both German and English influenced language patterns in the area.

In the beginning of the third millennium and 45 years after independence and the creation of the state Tanzania, I estimate that most Banyambo over 12 years of age are functionally bilingual in Swahili and Runyambo. Both languages are frequently used and most adults can use them for their daily communicative needs. English is a high status language that is mastered by only very few individuals in the upper classes, such as some higher officials and a few other highly educated persons.

Tanzania is among the poorer countries in the world and the educational challenges are tough. The situation for the primary schools in this study, which were five among the best rural schools in Karagwe, was challenging in many ways. Most classrooms had more than 50 students, in some cases more than 100 . The highest number of students was found in preschool and standards one and two. As the drop-out rate was high, classrooms in standard seven often had only 20-30 students. In the beginning of the study the lack of school books was high. Only some subjects had books and it was not unusual that four students had to share one book. During 2002 and 2003 the number of schoolbooks increased. As school buildings is the responsibility of parents, in many cases four students had to share a school desk designed for two and some classrooms had earthen floor. There were also cases were teaching had to take place outdoors.

\subsection{Theoretical background}

The linguistic situation in Karagwe, a multilingual setting, with one language used mainly in private domains and one mainly used in official domains, while other languages are used parallel to the main languages, is quite common in the world, particularly in poor settings. Similar situations, where children master one language when they enter school and are supposed to master another dominant language when they finish primary school, are found in several settings in the world and this is particularly common in former colonies. Research on bilingual education is quite impressive today and have been carried out by among others van Lier (1996), Cummins (2000, 2007), Heller and Martin-Jones (2001) and Hornberger and Chick (2001). A study by Thomas and Collier (1997, 2002) showed very impressively that the most important factor for children's success in bilingual education was that their mother tongue was strongly supported throughout their schooling (see also Cummins, 1996, 2000; Gibbons, 2002, 2006; Schleppegrell, 2004). It should not be very controversial to claim that children learn best when they are taught in a language that they understand. This is particularly important during the first years of schooling, when children are supposed to learn the three R's (reading, writing and arithmetic) as this is the base for later schooling (Cummins, 2000). This means that, in the case of Karagwe, children should gain a lot if they where to be taught Swahili as a second language, following research findings on bilingual education, while they should simultaneously have support in their mother tongue, Runyambo. This, however, is not the case. Following the official policy of using Swahili only from pre-school, very little Runyambo is used in classrooms, as this is against official policies.

Another important factor for children's success in second language acquisition in school is that what is done in school is based on their earlier knowledge and experience (Säljö, 2000). Research drawing on the findings by among others Shirley Brice Heath in Piedmont Carolina, USA (Heath, 1983), has stressed the importance of linking what happens in classrooms with what happens in the children's homes and surroundings. The importance of considering interactional patterns in classrooms has been stressed by many researchers, such as Mehan (1992), Au (1980), Ericksson (1986), Cazden (2001) and Watson-Gegeo (1992). In Hawaii, Au showed how the use of local patterns used in narration also in school, led to increased achievement in the education in the lower classes. In Kwara'ae (Solomon Islands), the local interactional pattern "shaping the mind" was introduced in schools with positive results (Watson-Gegeo, 1992).

\subsection{Children's language skills in primary school in Karagwe}

This study showed that nearly all children in Karagwe master Runyambo when they begin school but not Swahili (Wedin, 2004, 2005). Nearly all children in the countryside and perhaps more than $90 \%$ of the children in the towns know only a few words of Swahili when they begin school. I also found that children in Karagwe generally do not master Swahili until the last classes in primary school. According to my results it is not until in standard four or five that most students know Swahili well enough to be able to use it in ordinary conversation. This was verified by teachers. I asked teachers, for example, if they told children in lower classes stories but they answered that they could not do so as the children would not understand a story told in Swahili until higher classes. This means that teachers' perceptions in this case are similar to mine. However, I have found that probably most students who finish standard seven, i.e. the whole primary school, master Swahili on a functional level. I interviewed some of the students in standard seven with the lowest results and they could all discuss with me in Swahili on a level that I estimated as proper for their age. Some of the 
most low-performing students I also met in follow-up interviews 1 year after they had finished school and they were still fluent in Swahili. This shows that most students in my study acquire Swahili at least on a functional level through primary school as children in these rural areas rarely meet Swahili outside school. The domains where Swahili is used in Karagwe, apart from in schools, are mainly adult domains, such as offices, churches and market places.

\subsection{Interactional patterns in classrooms}

Through the observations and interviews in schools I understood that generally, the understanding of what was taught was very poor. Students often did not seem to have understood what had been taught at all. This of course has many reasons, but I conclude that one reason why most children could not retell anything of what had been taught even the day after the lesson had been given, or answer any questions on the content, is that thay are taught through a language that they do not master, at least not during the four or five first years of schooling.

What also became clear to me was that pupils and teachers had developed what I call safety strategies. These are strategies that are developed by teachers and pupils to create a picture of successful learning and to hide failure. In a situation as in Karagwe, where there are extremely high expectations on education while at the same time the conditions are extremely poor and thus also the outcome, teachers and pupils create ways to hide this failure to escape punishment and to "save their faces" (see also Hornberger and Chick, 2001 for similar examples from South Africa and Peru). Education is perceived as very important in Tanzania and particularly in Karagwe. In the earliest policies of the new state of Tanzania, the importance of education was stressed heavily (Nyerere, 1968). Education was expected to be the key to development and a better financial situation. Through my study I found that this was very much the case in Karagwe. People on all levels, both high and low educated, stressed the importance of education as a key for a better future. Teachers are expected to produce well-educated citizens and children are sent to school to be able to improve their families' economy in the future. In such a situation, with a cinsiderable gap between expectations and actual outcome, and in a hierarchical system where both teachers and students are frequently punished for failure, they are likely to create ways to hide their failures, i.e. safety strategies. This is what has happened in schools in Karagwe.

Teachers in the study tended, for example, mainly to address successful learners and not to follow up when students did not show any understanding. Students were supposed to hand in their exercise books after each lesson. This was usually only done by the more successful students, a fact that teachers seldom reacted on. Less successful students tended to hide in the back of the classroom and even not to show up at school at all. There is a saying among children in Karagwe that many of their mates wanajificha kichakani, they hide in the bushes. That means that they dress in the school uniform in the morning and leave their homes. However, they stop somewhere on the way to school and "hide in the bushes". This way they hope to escape the punishment they expect in school due to low performance and also the punishment they would receive at home if they refused going to school. This is seldom acted upon on the schools' part. (For other types of safety strategies, see Wedin, 2004).

One type of safety strategies that I discovered was a type of interactional pattern that guided students to give the expected answers without actually understanding. When I observed I found a chanting-like chorusing being used. This chorusing resembles the types of interaction observed in classrooms in poor settings elsewhere (Aziz, 1981; Watson-Gegeo, 1992; Ndayipfukamiye, 1994; Arthur, 1994, 2001; Chick, 1996; van Lier, 1996; Schieffelin, 1996; Heller and Martin-Jones, 2001). This chanting type of interaction soon becomes predictable to students and becomes

part of a system that Hornberger and Chick call safe-time (2001). I also noted that students were very skilled in guessing the answers expected by the teacher. Teachers are poorly trained and in many occasions I noted that teachers not only made mistakes but also were inconsistent. Thus, I occasionally had problems in predicting what answer the teacher was expecting. However, many times during my observations, I noticed that students managed to guess the "correct" answer when I did not.

I prefer to call the different strategies used to hide failure in classrooms safety strategies to include other strategies such as those mentioned earlier, and to call the prompt-answer interaction call-response as in all these cases the teacher, or another speaker, prompts or calls for response. ${ }^{1}$

I found four types of call-response used by teachers in primary schools in Karagwe:

1. Repetition: Pupils repeat words or parts of teachers' speech.

2. Confirmation: Teachers ask questions of the type: "Are we together?", "Do you understand?" and "Isn't it?" The answer is invariably: "Yes!"

3. Content-question: Teachers ask questions on the content taught.

4. Completion: Pupils are requested to complete words, clauses or sentences in the teachers' speech.

Teachers mark pupils' turns prosodically by using high tones and stress on the last syllable. (In Swahili stress is normally on the penultimate syllable) Often the teacher repeats the answer, or gives the correct one if pupils fail, in low tone. Pupils are also encouraged to shout their responses out loudly, which they do with great enthusiasm, and the pattern is explicitly trained in lower classes. I will give some examples from my observations. The first one, repetition, is commonly used in the lower classes. (Underlining denotes talk with high tone and italics denote talk in low tone.)

Example 1: Repetition
Mw: Hii ni a!
T: This is a!
W: Hii ni a!
Ps: This is a!

In this example we see that the teacher uses stress and high tone on the last syllable to call for pupils' chorusing. The second type, confirmation, is frequently used throughout primary school.

Example 2: Confirmation

Mw: Tunakunywa
maji safi, sivyo?

W: Ndiyo!

Mw: Eee?

W: Ndiyo!

Pupils' answer is invariably affirmative. They should never answer no. The third type resembles typical questions of test-type, also frequently used in schools elsewhere.

Example 3: Content-question
Mw: Tunaandika barua aina tatu. Tunaandika barua aina ngapi?

W: Tatu!

Mw: Tatu
T: We drink clean water, don't we?

$$
\text { Ps: Yes! }
$$

T: What?

Ps: Yes!

\footnotetext{
${ }^{1}$ Similar interaction patterns, that resemble what has been described here, have been observed among Afro-American priests and politicians in sermons and
} speeches (Smitherman, 1977).
T: We write three types of letters. How many types of letters do we write?

Ps: Three!

T: Three 
As we see, the answer is given prior to the question. In this case the teacher repeats the answer in low tone, which is also frequently done in these classrooms. This gives the interaction pattern its chanting character. It is also common that teachers leave the last part out like in the following example.

Example 4: Completion safi. Nyumbani tunaweka maji ...

W: Safi!

Mw: Safi

This last type, completion, is more abstract and is more often used in higher classes. In the following example from a classroom in standard 7 only the last syllable is left out:

Example 5:

Mw: Hapa unaandika shilingi,

hapa unaandika se...

W: Senti

T: Here you write shillings, here you write ce...

Ps: Cents

At first, the call-response interaction may seem to have the function of assessing pupils' knowledge, to help teachers make sure the pupils have understood. However, after a closer look, we find that pupils usually do not need to know the content to answer the questions. In the second type, confirmations, pupils would not answer no and in the other types the answer is usually given. What pupils need to understand is the interaction pattern. Thus I conclude, in agreement with Hornberger and Chick (2001), that the function of this type of interaction is mainly social, not cognitive. It gives teachers a chance to manage a seemingly impossible situation by giving pupils turns, camouflaged as test questions, testing pupils' knowledge, but in reality filling a social function. This is done in co-operation with the pupils. My studies confirm that students actively learn this skill. In pre-school and standard 1 the pattern was explicitly exercised. The following example from a pre-school classroom shows this.

Example 6:

Mw: Safi?

T: OKE?

W: Kabisa!

Ps: Absolutely!

Mw: Safi?

W: Kabisa!

Mw: Sasa mtakwenda

nje mucheze kidogo,

halafu murudi darasani

nitatoa hadithi, nitatoa nini?

\section{W: Hadithi \\ (...) \\ Mw: Safi? \\ W: Kabisa!}

Mw: Sasa tutasikiliza hadithi.

Nitatoa hadithi munisikilize

halafu mtatoa, sawa?

W: Ndiyo!

Mw: Sawa?

W: Ndiyo!

T: OKE?

Ps: Absolutely!

T: Now you will go out and play a little, then you shall return to the classroom and I will tell you a story, what will I tell?

Ps: A story

(...)

$\mathrm{T}: \mathrm{OK}$ ?

Ps: Absolutely!

T: Now we will listen to a story. I will tell a story and then you will tell, $\mathrm{OK}$ ?

Ps: Yes!

T: OK?

Ps: Yes!

In the following example it is clearly shown that pupils in lower classes have difficulties with language.

Example 7:
Mw: Nyumbani tunaweka maji
Mw: (...) ya pili inasema pamoja na kupewa zawadi, amepiga na nini?

W: Zawad

Mw: A a, amepiga na nini?

W: Mapicha

Mw: Ee?

W: Mapicha

Mw: Picha ni picha, amepiga?

W: Picha

$\mathrm{T}:(\ldots)$ and second it says

that together with being

given gifts, what has she taken?

S: Gif

T: No no, what has she taken?

S: Pictureses ${ }^{2}$

T: What?

S: Pictureses

T: Pictures it's pictures, she has taken?

T: Pictures
In this example, where the answer is not clearly given in advance by the teacher, we see that students make mistakes. In the first mistake (zawadi) they seem to use the same strategy as in example 6 , repeating the last word said by the teacher in the penultimate sentence. It shows that they do not understand what the teacher is saying as the verb-piga cannot be followed by a noun such as zawadi. Then we see that they elaborate on their Swahili as they put a Swahili-plural prefix on the word picha (pictures). However, in standard-Swahili loan-words, as this, do not take a plural-prefix.

I agree with Hornberger and Chick (2001), that one function of this type of interaction is to create safety by saving the face of teachers and pupils and that while this interaction hides the fact that nearly no academic learning is taking place, in fact, at the same time it prevents academic learning. As the interaction pattern serves to hide lack of knowledge, neither teachers nor students get to know the actual knowledge of the students. Thus the level of what is taught is likely to be far above the level that students can understand.

Hornberger and Chick claimed that the main reason for the development of such patterns is that a language that neither students nor teachers master is used as medium of instruction in classroom (2001). This is, however, not in accordance with the case of Karagwe, as the teachers actually master Swahili, the language of the classroom. Only students in the lower classes do not master it. In this case I see the gap between expectations and outcome as one causal factor, linguistic problems another and the hierarchical system with frequent use of punishment as a third.

\subsection{Call-response in the society}

However, since I did not end my study at the classroom door, but also studied language use in society, I found that this interactional pattern, with high and low tunes used in exchange between speaker and listener, is also actually used outside school, but in these cases not to hide failure. What I term call-response interaction is one feature very often used in some types of speech in Karagwe, such as narration, speeches and preaching, in ways that resemble the interactional patterns in classrooms. In Tanzania, talk-turns are generally longer than in, for example, Sweden. The speaker may "hold the floor" for a long time. Also, skills in giving speeches are well developed among Tanzanians. In many families, children are explicitly trained to give short speeches. This includes using techniques to activate the listener among which call-response is one.

In these contexts, the speaker also calls for the listener's feedback by using high tone and stress on the last syllable of what is said. In call-response the speaker calls for the listener to give, for example, some information in the narration or to give part of a

\footnotetext{
${ }^{2}$ Pictureses is spelled this way to show the double plural constructed by students through mapicha.
} 
word, as in the following examples. The first example is from a narration. A person is re-telling something that had happened to him the day before. ( $\mathrm{A}$ is the narrator and $\mathrm{B}$ is the listener).

Example 8:
A: Nilipofika niliona nini?
A: What did I see when I arrived? B: Mbwa B: The dog

In this example, contrary to the examples from the classrooms, the answer was not given immediately before but is implied in the narration. Thus, the listener is required to listen carefully and concentrate on what is said, to be able to give the right answer. The following example is from the same narration and here we see an example where only the last syllable is left out.

Example 9:
A: Nilimwo
A: I saw
B: na
B: him

In this example Nilimwona is one word in Swahili and the part left out is part of the verb-stem. Here it is clear that in these cases the listener is encouraged to actively take part in the narration. The same pattern is also used in formal religious activities, such as sermons, Bible studies and Sunday school. The evangelist or the priest often makes the congregation participate in different ways. In the following example, from a Pentecostal church, the priest uses call-response interaction in ways similar to narration in homes.

Example 10:

Mchungaji: Nani anataka Priest: Who wants to cheat us?

kutudanganya?

Msharika: Shetani

Member in the congregation: Satan

Mchungaji: Shetani

Priest: Satan

In Karagwe it is common that local leaders hold seminars for women's groups or groups of peasants. Here is an example of an experienced local female leader, Ma Eliza, discussing with women in a rural seminar. One woman has asked what she should do with a young man she has to support at home.

Example 11:

Ma Eliza: Mvulana wa miaka

kumi na nane ni mtu mzima, anaweza kufanya nini?

Akina mama: Kuoa

Ma Eliza: Kuoa

In this example Ma Eliza uses call-response interaction to make the women themselves provide the answer to the question. The use of call-response in all of these examples helps the listener to focus on what is said. It is an effective tool for speakers to make sure that the listener concentrates on the topic. Thus, this interactional pattern helps the speaker to get his or her message through and also activates the listener by helping him or her focus more on what is said. The main difference between the use of call-response interaction in school and outside is that it serves to hide failure in schools while it serves the function of involving the listener in what is said outside school.

\section{Discussion}

I conclude that the current policy of Swahili only in primary schools in Karagwe, together with the considerable gap between high expectations and small resources and the hierarchical system has resulted in the use of safety strategies among teachers and students, in pupils being sorted according to their language background and in low educational outcome overall. The chorusing that I call call-response, resembles the patterns found elsewhere in poor educational settings. As in the case studied by Hornberger and Chick (2001), call-response interaction serves to hide school failure and at the same time constitutes a hindrance for pupils' learning as it hides their real level of knowledge. However, I argue that in the case of Karagwe this interactional pattern at the same time could become a potential for education as it helps students focus on what is taught, to concentrate, and to memorize what is taught. It could thus provide teachers with tools for handling difficult classroom situations if the problem with hiding failure could be dealt with. The fact that call-response interaction in classrooms in the case of Karagwe builds on interactional patterns used in the society, gives this type of interactional pattern a potential for future development. As children have already met the pattern outside school, they are likely to gain from its use in classrooms. However, this demands that other ways to use it, without hiding students' real knowledge level, are developed. Research carried out in Australia (Gibbons, 2006, 2008), USA (Schleppegrell, 2004) and Canada (Cummins, 2000, 2007), on education in multilingual settings, could be a base for this. These studies have shown different ways of enhancing learning in schools by supporting both development of students' first language and the second language that is used in school.

It is a considerable waste of resources that linguistic background is made to constitute a sorting factor for schooled education, and it is at the same time undemocratic. Large amounts of resources are ineffectively used in education in Karagwe as so much teaching is carried out in a language that students do not understand (Rubagumya, 1994; Blommaert, 1996; Brock-Utne, 2000; Wedin, 2004). Furthermore large numbers of children are not given a fair chance to learn what they should, as they actually do not understand what is said during a great part of primary school because the language used is one that they do not understand. When education is regarded as highly important, when people put so much effort into education, so many teachers work extremely hard, so many children spend lot of time in school with hard work and so many parents spend more money that they can afford to educate their children, as is the case in Karagwe, then one should demand that these resources be used in ways that are effective and relevant.

If policy makers would accept the fact that most pupils have another language than Swahili as their mother tongue, then the language question in primary school in Tanzania could also be open to discussion, and findings from relevant research on second language education for children in primary school could be taken into account (Gibbons, 2006, 2008; Schleppegrell, 2004; Cummins, 2000, 2007). Examples of successful teaching, both of a second language and academic content in situations similar to the one in Karagwe, and examples of how children have been successfully taught in a second language, which Swahili is for children in Karagwe, are many. Findings could then be used as a base for developing language policies, as has been suggested earlier for secondary school (Rubagumya, 1990, 1994).

Prevailing interaction patterns that constitute an obstacle for efficient learning, could be changed by adapting them to interactional patterns used in society and the use of the language that students master, Runyambo, at least during the early years of schooling could make learning much easier. As these patterns in society are used to make listeners pay more attention and focus on what is said, they constitute a potential for the development of more relevant and efficient interaction patterns in classrooms. To help listeners focus on what is said is also very relevant for 
classrooms, particularly in poor settings where teacher talk is the main teaching tool. If interaction patterns in classrooms could be adapted so that they still make pupils listen but without hiding failure and thus preventing teachers and pupils from understanding pupils' real knowledge level, then teaching could become more relevant and learning could increase. Using Runyambo in the early years of schooling, parallel to Swahili, could simplify teaching and learning and thus decrease the gap between expected and real outcome.

However, I also want to stress that to make this successful, the developing of new teaching methods should be carried out by policy makers, teachers, teacher educators and linguists in cooperation. To copy examples from other contexts uncritically, such as education in western schools, should be avoided. To change interaction patterns in classrooms is difficult, as they are often unconscious. The problems with the gap between expected outcome and real outcome, and the problems with punishment for perceived failure, should be considered in this context. As long as teachers and students experience a need to hide failure they will continue to do that, no matter what interactional patterns they will be taught. This means that the first step should be that policy makers and those in power be made aware of the problem to enable a positive change.

\section{Acknowledgements}

This study was made possible by the support of Högskolan Dalarna, Sweden, and by a generous research grant from SIDA/ SAREC. I also want to thank two anonymous reviewers for valuable comments on an earlier version of the article.

\section{References}

Arthur, J. 1994. English in Botswana primary classrooms: functions and constraints. In: Rubagumya, C.M. (Ed.), Teaching and Researching Language in African Classrooms. Multilingual Matters Ltd., Clevedon.

Arthur, J., 2001. Code-switching and collusion: classroom interaction in Botswana primary schools. In: Heller, M., Martin-Jones, M. (Eds.), Voices of Authority. Education and Linguistic Difference. Ablex Publishing, USA.

Au, K., 1980. Participation structures in a reading lesson with Hawaiian children. Anthropology and Education Quarterly 11, 91-115.

Aziz, A.A., 1981. Strategies for Communication between Teachers and Pupils in a Rural Malaysian School. Singapore University Press, Singapore.

Blommaert, 1996. State Ideology and Language in Tanzania. Rüdiger Köppe Verlag, Köln.

Brock-Utne, B., 2000. Whose Education for All?: The Recolonisation of the African Mind. Falmer Press, London.

Buchert, L., 1994. Education in the Development of Tanzania 1919-1990. Mkuki na Nyota Publishers, Dar-es-Salaam.

Cazden, C., 2001. Classroom Discourse. The Language of Teaching and Learning. Heinemann, Portsmouth.

Chick, J.K., 1996. Safetalk: collusion in apartheid education. In: Coleman, H. (Ed.) Society and the Language Classroom. Cambridge University Press, Cambridge.

Cummins, J., 1996. Negotiating Identities: education for empowerment in a Diverse Society. California Association for Bilingual Education, Ontario.

Cummins, J., 2000. Language, Power and Pedagogy. Bilingual Children in the Crossfire. Multilingual Matters, Clevedon.
Cummins, J., 2007. Identity texts. The imaginative construction of self through multiliteracies pedagogy. In: García, O., Skutnabb-Kangas, T., Torres-Guzmán, M.E. (Eds.), Imaging Multilingual Schools. Languages in Education and Glocalization. Multilingual Matters, Clevedon.

Ericksson, F., 1986. Qualitative methods in research on teaching. In: Wittrock, M.C. (Ed.), Handbook of Research on Teaching: A Project of the American Educational Research Association. 3rd ed. MacMillan, New York, pp. 119-161.

Gibbons, P., 2002. Scaffolding Language Scaffolding Learning. Teaching Second Language Learners in a Mainstream Classroom. Heinemann, Portsmouth, NH.

Gibbons, P. 2006. Bridging Discourses in the ESL Classroom. Students, Teachers and Researchers. Continuum, London.

Gibbons, P., 2008. "It was taught good and I learned a lot": intellectual practices and ESL learners in the middle years. Australian Journal of Language and Literacy 31 (2), 155-173.

Heath, S.B., 1983. Ways with Words: Language Life and Work in Communities and Classrooms. Cambridge University Press in Social Anthropology, Cambridge, p. 43.

Heller, M., Martin-Jones, M. (Eds.), 2001. Voices of Authority. Education and Linguistic Difference. Ablex Publishing, USA.

Hornberger, N., Chick, K., 2001. Co-constructing school safetime. Safetalk practices in Peruvian and South African classrooms. In: Heller, M. Martin-Jones, M. (Eds.), Voices of Authority. Education and Linguistic Difference. Ablex Publishing, USA.

Lwaitama, A.F., Rugemalira, J.M., 1990. The English language support project in Tanzania. In: Rubagumya, C.M. (Ed.), Language and Education in Africa: A Tanzanian Perspective. Multilingual Matters, Clevedon, Philadelphia.

Mehan, H., 1992. Understanding inequality in schools: the contribution of interpretive studies. Sociology of Education 65, 1-20.

Ndayipfukamiye, L., 1994. Code-switching in Burundi primary classrooms. In: Rubagumya, C.M. (Ed.), Language and Education in Africa: A Tanzanian Perspective. Multilingual Matters, Clevedon, Philadelphia.

Nyerere, J.K., 1968. Freedom and Socialism/Uhuru na Ujamaa-A Selection from Writings and Speeches 1965-1967. Oxford University Press, Dar-es-Salaam.

Rubagumya, C.M. (Ed.), 1990. Language in Education in Africa: A Tanzanian Perspective. Multilingual Matters, Clevedon, Philadelphia.

Rubagumya, C.M., 1994. Teaching and Researching Language in African Classrooms. Multilingual Matters Ltd., Clevedon.

Säljö, R., 2000. Lärande i praktiken-ett sociokulturellt perspektiv. Prisma, Stockholm.

Schieffelin, B.B., 1996. Making sense of written words in Bosavi. In: Ochs, E., Schlegloff, E.A., Thompson, S.A. (Eds.), Interaction and Grammar. Oxford University Press, Oxford.

Schleppegrell, M., 2004. The Language of Schooling. Lawrence Erlbaum, London.

Smitherman, G., 1977. Talkin and Testifyin, The language of Black America. Houghton Mifflin Company, Boston.

Thomas, W., Collier, V., 1997. School Effectiveness for Language Minority Students. NCBE Resource Collection Series, No. 9, George Washington University. http:// www.ncbe.gwu.edu/ncbepubs/resource/effectiveness.

Thomas, W., Collier, V., 2002. Reforming educational policies for English language learners means better schools for all. The States Educational Standard 3 (1) (The quarterly journal of the National association of State Boards of Education, Alexandria, Virginia).

Trappes-Lomax, H.R., 1990. Can a foreign language be a national medium? In: Rubagumya, C.M. (Ed.), Language in Education in Africa: A Tanzanian Perspective. Multilingual Matters, Clevedon, Philadelphia.

van Lier, L., 1996. Conflicting voices: language, classrooms and bilingual education in Puno. In: Bailey, K.M., Nunan, D. (Eds.), Voices from the Language Classroom: Qualitative Research in Second Language Education. Cambridge University Press, Cambridge, pp. 367-387.

Watson-Gegeo, K.-A., 1992. Thick explanation in the ethnographic study of child socialization: a longitudinal study of the problem of schooling for Kwara'ae (Solomon Islands) children. New Directions for Child Development 58, 51-66.

Wedin, A. 2004 Literacy Practices In and Out of School in Karagwe-The Case of Primary School Literacy Education in Rural Tanzania. Centre for research on Bilingualism, Stockholm University, Stockholm.

Wedin, A., 2005. Language ideologies and schooled education in rural Tanzania-the case of Karagwe. International Journal of Bilingualism and Bilingual Education 8 (6), 568-588. 